Implications of religion, culture and legislation

\title{
Implications of Religion, Culture and Legislation for Gender Equality at Work: Qualitative Insights from Jordan
}

\begin{abstract}
With a view to consolidating the existing theory development and stimulating new conceptual thinking, this paper explores the implications of culture, religion (Islam) and the legal framework on women's employment and their limited advancement in the hospitality industry, one of the important elements of the economy in Jordan. A related aim is to contrast the egalitarian Islamic approach to gender equality with gender discriminatory tribal traditions that restrict women's employment and progression. Guided by religion, culture and gender literature, this study uses a qualitative, content-based analysis. Drawing on openended questionnaires distributed to a diverse workforce across four tourist locations in Jordan, the results portray how tribalism and Bedouin customs embedded in the participants' interpretation and practices of their religion (along with the existing legal framework) are maintaining gender gaps in employment and positions of power. The results also reveal that despite the Islamic guidelines towards fairness and justice (haqq and adl) in employment, the tribal and Bedouin traditions restrict women's employment through patriarchal interpretations of Islam. Thus, the salient novelty and significance of this study were achieved through contributing to the theory development of the interrelations between religion, culture and gender equality.
\end{abstract}

Keywords: Female leadership, Gender, Legislation, Quran, Religion, Tribalism 
Implications of religion, culture and legislation

\section{Introduction}

In an increasingly globalized world, Muslim majority countries (MMCs) face challenges of social justice (or lack thereof) and gender inequality (Metcalfe, 2008). The literature on female leadership indicates an underrepresentation of women in positions of power and, the existence of negative stereotypes about women (e.g. Eagly and Karau, 2002). For women, this is an issue of equal opportunities and justice in their economic participation; it also motivates scholars to pay attention to the field of gender diversity in leadership ( $\mathrm{Du}, 2016)$.

Although the proportion of women in the workplace has increased within the past few decades, women in the Arab region remain vastly under-represented in leadership and positions of power. In Jordan, only 2 women out of 27 are ministers, 2 women out of 28 are appointed at secretary general level, 6 women out of 50 are appointed at director general level, and just one woman out of 25 is appointed at governor level (Statistics Department, 2011 cited in United Nations Development Programme, 2012). In the Jordanian parliament, in the aftermath of the elections that were held in 2016, only 20 seats out of 130 are occupied by females (i.e. 15.38\%) (Inter-Parliamentary Union, 2016).

Moreover, industries where more women are expected to be employed, such as the hospitality industry, remain male-dominated, particularly in the upper echelons of management (Masadeh, 2013). According to the Social Security Corporation (2014), in the manufacturing, construction, tourism and transportation industries, the employment gender gap is found to be $44.0 \%, 84.4 \%, 85.3 \%$ and $63.3 \%$ respectively. The gender gap is at the highest level in the hotel sector in which the number of female workers is 1.529 in comparison to 17.392 male workers (Ministry of Tourism and Antiquities, 2015). This wastage of human capital has attracted us to study some contextual factors that may explain the gender gap in Jordan. 
Implications of religion, culture and legislation

Religious and cultural practices have caught the attention of academics and practitioners due to their overlap with other work-related behaviors. The status of women in Islam has been an issue of debate (Malik, 1980; Rizzo, 2017). It has been argued that at least some of the misconceptions arise from traditions that are perceived to be Islamic, whereas they are not (Mehar, 2003, p. 214). In the Arab region, the role of religion remains underresearched in business and management studies (Tlaiss, 2015). While attention has been paid to other elements of diversity in leadership, such as country-specific factors, corporate governance and economic development level ( $\mathrm{Du}, 2016)$, the literature offers little evidence on the interrelationship between cultural/religious factors and gender equality in leadership and employment. This paper seeks to fill this gap by examining how tribal culture and Islam in Jordan affect gender diversity in leadership.

The legislative context is another related factor that shapes gender equality in a given society. Based on our review of the labor law, Article 6 in the Jordanian constitution clearly excludes anti-discrimination practices against gender: "Jordanians shall be equal before the law, with no discrimination between them in rights and duties even if they differ in race, language or religion." (Jordan Constitution, Article 6, S1). Another peculiar point that emerges from our review (i.e. Article 69), is that the Minister of Labor can decide on industries and jobs prohibited to women (Lohmann, 2011; Peebles et al., 2007), whereby women's freedom of choice will be restricted. This exclusion of anti-discrimination practices against gender attracted us to explore the implications of laws on gender justice.

This study will contribute to the hospitality management literature by moving beyond the general conception and stereotypes that hold women back, to examine how Islam, culture and law may justify the unbalanced gender situation. Specifically, this study challenges the general conception prevailing in some circles in Jordan and elsewhere that portrays Islam as a source that holds Muslim women back, by showing that tribal customs or cultural traditions 
Implications of religion, culture and legislation

are the primary influence. Further, this paper identifies an opportunity to reform patriarchal interpretations of religion (Islam) towards egalitarian interpretations and practices.

The paper is organized as follows. First, a conceptual discussion is offered to explain the intricate interrelationship between gender, religion and culture. Second, a review of the literature on Islam, tribal culture and women's employment is presented. Third, a discussion about the hospitality industry in Jordan is offered, which highlights issues of gender and inequality. Fourth, the research methodology and analysis techniques are explained. Finally, we present and discuss the emerging themes, and implications for practice and research.

\section{Theoretical grounding}

In the context of religion and gender, and to address the challenge of the relevance of conventional Western theories in the Islamic Middle East, this study focuses on the inconsistency in Islamic interpretations and practices with regard to 'appropriate' female gender role. This helps to contrast the egalitarian Islamic efforts on gender equality with the tribal and patriarchal traditions that restrict women's employment and progression.

In this paper, feminist theory on religion has been used to articulate and underpin our discussion. This theory highlights women's status not in terms of gender and feminine identity, but rather in cultural-religious terms. It recognizes wo(men) as socio-cultural "subject who are producing cultural knowledges and religious discourses" (Fiorenza, 2013, p. 43).

Scholarship on the convergence of Islam and feminism includes, first, refusing the possibility of a convergence and keeping the two concepts apart, and second, naming the convergence "Islamic feminism". Thirdly, there are scholars who challenge how the convergence of Islam and feminism is presented, and resist the application of the label "feminist" to their work. Finally, there is scholarship that allows for the convergence by referring to Islamic teachings in the application of feminist analysis (Seedat, 2013). The 
Implications of religion, culture and legislation

present study builds upon the notion of the convergence of Islam and feminism by referring to Islamic teachings to understand the linkages between Islam, women and the prevailing culture and traditions. This may also help to show the complexity and diversity of gender analysis in MMCs.

Feminist theory offers two social analytics for exploring wo/men's position in society and religion: one is the analytics of gender; the other is the analytics of the intersectionality of oppression (Fiorenza, 2013). In this paper, we link these two analytics to understand "Islamic women's status" within an Arab culture better. Feminist theory on religion suggests that women in the Arab world (Middle East) encounter problems augmented by the patriarchal (tribal) "nature of their culture and by misinterpretations of Islam's teachings" (Tlaiss, 2015, p. 860). While tribal values and discriminatory stereotypes against females continue to restrict women's careers, they are aggravated in Muslim countries by the reappearance of "certain pre-Islamic customs" (Jawad, 1998, p. 24).

Islamic feminist theory suggests that Islam absolves women of economic responsibility, an option which is left to the woman's personal choice and needs. This is in direct contrast to the position of men in the Arab region, who are duty bound to support their families. Given that women are not religiously duty obliged to support their families financially, they are less likely to seek paid jobs (Syed and Van Buren, 2014).

Islamic feminists provide new Islamic discourses that challenge the male ascendancy and patriarchal interpretation of the Qur'an. They argue, as examples, that the Qur'an devotes a whole surah to women. Also it repeatedly states that Muslim women have the same religious duties as men. In addition, the Qur'an appreciates examples of strong women such as, Mary (the virgin mother of Jesus), Khadijah, the first wife of Muhammad and Fatima his beloved daughter (King, 2009). Mehar (2003) argues that there are provisions within Islamic teachings that give women "the greatest social value, freedom, and comfort" (p. 214). 
Implications of religion, culture and legislation

To comprehend better how feminist theories and religious practices interact in a nonArab/Middle East region, we reviewed Western feminist and religion studies. As gender and religion literature dated back to the 1970s, its scholars often understand religion negatively, as a hurdle to feminism (Aune, 2015). However, in the late twentieth century, women's lives diversified, giving women freedom beyond the private sphere (e.g. home) and women's aspirations have aligned with diverse options e.g. employment, travel, education (Aune, 2015). In practice, as King (2009) notes, recently women have emerged in elite positions in Islamic countries (e.g. in the Arab region and elsewhere), by which "the woman's movement has become one of the most potent social movement" campaigning for justice and equity ( $\mathrm{p}$. 293).

Islam and Muslims are generally perceived as having an approach to gender practices much different from a Western approach to equal opportunity (Syed and Van Buren, 2014). However, Sechzer (2004) argues that one should be cautious not to either over-simplify or over-generalize the image of Muslim women, not least because of the changes in how Islam is viewed and the cultural changes taking place in many Muslims countries. Implicit in this argument is that despite the diversity in feminist or gender theories and studies, they share the same notion, "notably the recognition of male dominance in social arrangements", and a desire for changing this situation (Calás and Smircich, 1996, p. 213). In the present study, we highlight the textual flexibility of the Quran and other principal Islamic teachings (i.e. range of interpretations they offer) and contrast it with a given "Islamic" view of women prevalent in a place like Jordan. We argue that an egalitarian Islamic approach (or interpretation) to gender may be in conflict with gender discriminatory cultural traditions and tribal practices.

Previous research has offered a lack of insight into the relationship between religion, cultural-factors and gender practices (Maltby et al., 2010). As argued by Llewellyn and Trzebiatowska (2013), much as "male-stream academia has marginalized feminist 
Implications of religion, culture and legislation

scholarship, feminist scholarship has marginalized religion and gender" (p. 245). Hence we seek to fill this gap by studying the interrelationship between religion and gender. The next section illustrates in further detail the linkages between Islam, tribal culture and women.

\section{Women's status in Islam}

Despite pro-justice injunctions within Islamic theology (Sabri, 2011), "like other religious traditions, Islam lends itself to multiple interpretations of doctrine that are plausible in different contexts" (Syed and Van Buren, 2014, p. 257). The textual flexibility of religion is sometimes used to justify and maintain control in a particular social structure, whether that of capitalism, feudalism or patriarchy (King, 2009, P.321). In the context of the Arab/patriarchal world, people (in places like Jordan) portray female leaders as 'obstacle-laden' (e.g. AbuRabia-Quader and Oplatka, 2008; Metcalfe, 2008; Sawalha and Meaton, 2012), and it has been suggested that women in this region encounter problems that are augmented through "misinterpretations of Islam's teachings" (Tlaiss, 2015, p. 860) and the patriarchal nature of culture.

In MMCs, life and work are directed by Islam through the ethical values outlined in two main sources of religious teachings. The first is the Holy Quran which is the verbatim word of God (Allah), while the second one is the Sunnah (or Hadith), which is the legacy of the Prophet that entails his words, acts, and deeds (Tlaiss, 2015). This section reviews the Islamic view of women in terms of women's rights and equality with men, by reviewing a number of examples from these principal Islamic texts, with a view to understand the context of women employment through an Islamic lens better.

According to the Quran, women and men "constitute part of a single totality", and the differences between males and females are not just based on their sexual divisions, but on the nature of their ethical or moral character (Barlas, 2001, p. 132). For example, the following Quranic verse shows that humans differ based on their righteous conduct, not based on their 
Implications of religion, culture and legislation

sex/gender. Because the actual text of Quran is in Arabic, we present the following Quranic verse in both Arabic and English.

"O mankind! We created you from a single (pair) of a male and a female, and made you into nations and tribes, that ye may know each other (not that ye may despise (each other). Verily the most honoured of you in the sight of Allah is (he who is) the most righteous of you. And Allah has full knowledge and is well acquainted (with all things)" (49:13).

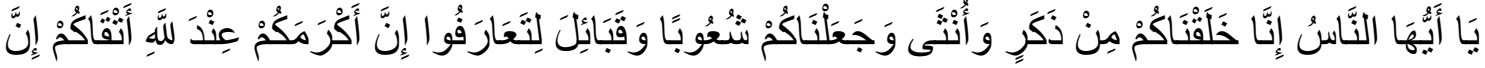

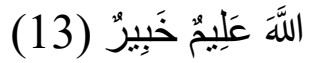

Furthermore, there are other verses in the Quran that point towards equality practices between genders. One such verse is: "O mankind! reverence your Guardian-Lord, who created you from a single person, created, of like nature, His mate, and from them twain scattered (like seeds) countless men and women; reverence Allah, through whom ye demand your mutual (rights), and (reverence) the wombs (That bore you)" (4:1). In another verse, the Quran says, "Never will I suffer to be lost the work of any of you, be he/she male or female: you are members, one of another" (3:195).

The significance of Islam in organizing social practices is reflected in studies that focus on how the Quran and Hadith offer moral guidelines (Metcalfe, 2008). Syed and Ali (2010) note that both the Quran and the Hadith encourage people to avoid gender discrimination and inequality. These texts do not differentiate between males and females, neither in terms of work, nor in terms of the social division of labor (Barlas, 2001), and therefore, both sexes should "be treated differently, not unequally" (Metcalfe, 2008, p. 91). In addition, the English convert to Islam and Qur'an translator, Pickthall (1925), notes that 'the historical truth is that the Prophet of Islam is the greatest feminist the world has ever known'. 
Implications of religion, culture and legislation

Akhmetova (2016) notes that Islam brought a general enhancement for women in ancient Arabia. For example, Islam offered women rights to property/inheritance, protection against ill treatment of their husbands, and respect in social life. Islam strictly prevented the practice of female infanticide in pagan Arabia (Syed and Van Buren, 2014). Armstrong, a Western expert on Islam, makes the following comment:

We must remember what life had been like for women in the pre-Islamic period when female infanticide was the norm and when women had no rights at all. Like slaves, women were treated as an inferior species who had no legal existence. In such a primitive world, what Muhammad achieved for women was extraordinary. The very idea that a woman could be witness or could inherit anything at all in her own right was astonishing. (Armstrong, 1992: p.191)

However, despite the Islamic teachings towards gender justice, there is a dominant patriarchal lens in MMCs, which forces working women to struggle more than men (Afiouni, 2014). For example, many people in Arab countries perceive females as mothers and housekeepers (Dougherty, 2010), which in turn leads to adverse stereotypes and unequal treatment within organizations.

In a study that seeks to reform patriarchal interpretations of Islam towards gender equality, Syed and Van Buren (2014) note that in Islam there are directions that support complementarity and encourage enlargement diversity strategies. Metcalfe (2008, p. 85), in her study of women and management in the Middle East, notes that women's limited advancement in businesses results from the existence of the patriarchal system within institutions, "which create strongly defined gender roles". Similarly, Barlas (2001, p. 122) argues that the repressive and exclusive practices towards women are justified by the patriarchal exegesis, which in turn represents "Islam as oppressive". 
Implications of religion, culture and legislation

Furthermore, historical and political factors affect how people interpret and understand Islam. For example, Marlow (1997) argues that after Prophet Muhammad, Islamic scholars began to rationalize the tribal system, which led in turn to a deviation from the textual flexibility of the Quran, as interpreted by Muslims, that supports gender egalitarianism (cited in Syed and Van Buren, 2014). Therefore, in reviewing the theoretical studies from the Middle East and MMCs on religion and gender relations, Syed and Van Buren (2014) note that there are partial counter-views that emphasize egalitarian practices of Islamic theology and conjunction with patriarchal interpretations and practices which affect women in organizations by imposing them to act in an accepted way in the society (Afiouni, 2014).

The next section focuses on the cultural and tribal traditions in the Arab and Jordanian contexts, and also sheds light on legislation and regulations in Jordan, with a view to explaining how such issues may justify the under-representation of women in the labor market.

\section{Tribal and patriarchal culture}

As Arabs were originally desert Bedouins, the relationship between Arab stereotypes and Bedouin prototypes has not ceased (Patai, 2002, cited in Sabri, 2011). Previous studies show that in the Middle East, the patriarchal structure revolves around and is embedded in gender and work-based relations. The patriarchal traditions in Jordan restrict women's upward mobility in work and sustain sex-segregated work spaces (Metcalfe, 2008). The conceptualization of tribal or Bedouin traditions, and their implications for women, is informed by the existing ongoing debates. This section, therefore, discusses the complexities of conceptualizing the implications of tribal and Bedouin customs on women's equality and employment.

In their study of female leaders in Bedouin societies, Abu-Rabia-Quader and Oplatka (2008) note that the connections between feminine styles of leadership and accessing 
Implications of religion, culture and legislation

positions of power are restricted by different cultural beliefs. Thus, they argue that when females work in male-dominated jobs, especially under patriarchal systems/organizations, they need to demonstrate their professionalism by adopting more masculine traits and playing their role as "honorable wives" in order to enhance their family's image within society.

Sawalha and Meaton (2012) conducted a study to explore the impact of the tribal system on women in Jordan. They note that the Middle East region consists of conservative countries that follow tribalism and pursue gender-specific separation. Similarly, in terms of cultural typologies of masculinity and femininity, Hofstede (1984) notes that the Arab region is masculine-oriented and applies patriarchal ways of management. This relegates what is socially perceived as feminine to a less privileged position (Sawalha and Meaton, 2012). In relation to Jordan, the tribal customs largely impact women's employment and progression. According to the World Bank (2014), a key justification for the limited participation of women and the continued inequality in Jordan is the obstructive social and cultural values. Hence, Sonbol (2003) argues that tribalism leads to the continuation of the patriarchal order and further inequality.

Abu-Rabia-Queder (2007) examined different models of female leadership in Bedouin cultures. Her study shows that there are different sources of gender discrimination in Bedouin and patriarchal societies. For instance, one cause of gender inequality is the honor/shame behavior some societies demonstrate. For example, some females struggle to access some public spheres, such as employment, because their families are afraid that they will bring shame/disgrace to the family by meeting "non-Mahram" males/men (Abu-RabiaQueder, 2007). Therefore, in Bedouin societies, women are expected and encouraged to act as honorable females in order to protect the image of their tribe/family and hence, in terms of females in leadership positions, Abu-Rabia-Quader and Oplatka (2008) note that the term 
Implications of religion, culture and legislation

"female leader" in Bedouin/tribal society is not common. Consequently, women in Arab countries struggle to access elite positions.

To deal with this peculiar case, women in Arab societies use Islamic texts and sources to challenge patriarchy and cultural taboos, because some of the social/Bedouin practices "are in opposition to the dictates of Islam" (Abu-Rabia-Queder, 2007, p. 76). As an example, Abu-Rabia-Queder (2007, p. 76) notes that Muslim women have the right to marry men from different tribes, however, some Bedouin beliefs largely prohibit marriages between individuals from different tribes. Thus, she argues that Bedouin societies and Islamic societies are not the same, because in Bedouin communities, tribalism shapes people's behavior and beliefs in ways that contradict some of the Islamic or Sharia laws, such as marital and employment restrictions. Therefore, to challenge such patriarchy and tribal restrictions, women "cope by reminding their community of its religious roots" (Abu-RabiaQueder, 2007, p. 82)

Overall, in Jordan, practices of management and leadership are generally premised on tribal Bedouin traditions, which revolve around the 'Bedou-cracy' and 'Sheikho-cracy' models, i.e. the primacy of the Bedouin culture and the typical superiority of the male tribal chief.

\section{Legislation in Jordan}

Jordan has taken several legal steps towards equality, human rights and justice. Texts that protect human/citizen rights take into account issues related to ethnicity, social class and religion (JNCW, 2011). For example, Article 6 in the Jordanian constitution clearly states that "Jordanians shall be equal before the law, with no discrimination between them in rights and duties even if they differ in race, language or religion." (Jordan Constitution, Article 6, S1). While Article 6 pays further attention to equality between people with different `races`, 'languages' and 'religions', a major question arises here, namely, why these anti- 
Implications of religion, culture and legislation

discrimination initiatives ignore differences between 'genders`. This exclusion of antidiscrimination practices against gender attracted us to explore the implications of laws on gender justice.

Owing to the social roots of some of the restrictions facing women, changes in the law are not simply a surrogate for other factors, e.g., tribal culture and patriarchal (mis)interpretation of religion. The following provisions in the Jordanian labor law indicate that some of these laws were established to fit with the pervasive culture and traditions.

According to the 1996 Labor Code (Article 69), night work between 7 p.m. and 6 a.m. is prohibited for women "except in the instances specified by decision of the Ministry of labor". Also, there are issues of discrimination against married or pregnant employees, or those with children. One example is that the Labor Code provides women one year leave without pay for childcare purposes. Further, the mother is granted only a total of one hour per day to nurse her child for one year after delivery (Article 71). This law reflects a patriarchal culture that recognises parenting as solely a female responsibility (Lohmann, 2011; Peebles et al., 2007). Another peculiar point is that the 1996 Labor Code (No. 8) forbids the termination of pregnant women after the sixth month of pregnancy as well as working mothers during their maternity leave (Article 27). These legal provisions sometimes operate as a disincentive for employers to hire women (Sonbol, 2003). Thus, in addition to legal reforms, it is important to understand and reform the gender discriminatory culture and tribal traditions, which in turn affect legislation.

Interestingly, Jordan is a signatory to the International Bill of Human Rights, which includes six conventions of human rights and it has been very responsive to gender equality obligations (JNCW, 2011; UNDP, 2012). In 1980, Jordan became a signatory to the Convention on the Elimination of All Forms of Discrimination Against Women (CEDAW) and ratified it in 1992. However, the country has expressed some reservations to some 
Implications of religion, culture and legislation

articles (e.g. 9, 15 and 16) regarding parents' equal rights, mobility, choosing the family name and the nationality rights of children. In 2007, like other Arab countries (e.g. Oman, Bahrain and Syria), Jordan endorsed CEDAW, whilst keeping its old reservations.

The government of Jordan has implemented some legislative and regulatory reforms that may enhance women's agency, through certain revisions to the Personal Status Code, and through the application of other laws that have the potential to give women equal rights to men (World Bank, 2013). This includes the establishment of the Jordanian National Commission for Women (JNCW) in 1992, an initiative from Prince Basma set up to facilitate greater appreciation of Jordanian women. 22 members are represented in the JNCW, including private and academic sectors, civil society organizations, national institutions, women agencies and ministries (JNCW, 2011).

In addition to these steps and initiatives towards human rights, there are additional plans in Jordan for the economic advancement of women. For example, two projects that have been launched by the UN as an executing agency for the empowerment of women. The first one is 'Women's Economic Empowerment' in the tourism sector, and the second one is the 'Regional Technical Resource Network for Women's Small and Micro Enterprises in the Arab Region'.

Overall, although serious steps have been taken by policy makers and the government to address gender equality, the issue of gender discriminatory social norms and customs still remains. This indicates that if the tribal culture and patriarchal interpretations of Islam remain fixed, it is arguable that these laws enshrined in legislation are weak tools through which to reform discriminatory practice against women, and sometimes these reforms and laws can be seen as problematic when they contradict the local social norms (Clifton, 2014). Hence, the present paper is interested in understanding more deeply the overlap between the legislative 
Implications of religion, culture and legislation

framework and other contextual and societal beliefs that may explain the rarity of women in the work place.

\section{The study: Females in Jordan's hotel sector}

Travel and tourism industry is one of the main industries in Jordan that contributes directly to the economy. According to Turner and Freiermuth (2017), this sector's contribution represented about $19.4 \%$ of GDP, $8.8 \%$ of the total investment and $5.1 \%$ of the total employment in 2016. However, due to its shift-type nature and services rendered, the sector is perceived to be a less likely place for female employment. Job requirements in this industry may demonstrate some incongruity with female social roles, such as contact with unrelated (Non-mahram) people. Similarly, given that this sector requires females to conduct night-shift duties, travel and demands long hours of work, there will be some cultural norms that restrict their employment and advancement (Majcher-Teleon and Ben Slimène, 2009). As a result, in the hotel sector there may be gender practices, stereotyping and prejudices against females (Marco, 2012) that could maintain the gender gap in practice. Table 1 illustrates some key facts about gender segregation in the Jordanian tourism sector.

\section{Insert Table 1 about here}

Given that female participation in the workplace is at its lowest level in the hotel sector, this study concentrates on 4-star and 5-star hotels operating in the most popular tourist locations in Jordan (i.e. Amman, Aqaba, Dead Sea and Petra). Table 2 shows the numbers of employees distributed in 4-star and 5-star hotels by gender and governorate (Ministry of Tourism and Antiquities, 2015).

\section{Insert Table 2 about here}

Considering gender dynamics in hospitality studies is a promising avenue and merits further research (Kogovsek and Kogovsek, 2015) given the lack of research on gender practices in this industry (Ferguson, 2011). 
Implications of religion, culture and legislation

\section{The Method}

A content analysis is used in this study to interpret "the content of text data through the systematic classification process of coding and identifying themes or patterns" (Hsieh and Shannon, 2005, p. 1278). Following this approach, the analysis starts from broad notions towards more specific observations, the conclusions/themes emanate from the data, and the inductive way of reasoning is used (Blumer, 2015).

\section{Research design}

Based on the literature review, the three main categories we investigated are: the cultural typologies of tribalism and Bedouins, the role of Islam as a religion (e.g. Syed and Ali, 2010) and the legislative framework on gender equality in Jordan. Due to the sensitivity of the topic in tribal societies, we used open-ended questionnaires on a paper-based survey, which provides participants with complete privacy and anonymity.

Open-ended questionnaires were distributed for employees working in 4-star and 5star hotels operating in different geographic locations in Jordan (Amman, Aqaba, Dead Sea and Petra) during the months from June to August 2016. In total, 178 questionnaires were received. In this sample, 40 participants were females, while 137 were males $(22.4 \%$ and $77.6 \%$ respectively). One participant did not identify their gender. This gap between gender participation was expected, since the gap between female employees and male employees in the hotel sector is considerable. Relevant responses were classified into short (i.e. without explanation) and long (i.e. with explanation) answers as follows: 108 questionnaire included short answers, 68 questionnaire included long answers and 2 questionnaires were not

relevant. With further concentration on the in-depth answers, this paper conducted the analysis procedure. 
Implications of religion, culture and legislation

The questionnaire was distributed by the first author through initial contact with Human Resource Managers or Directors who work in these hotels by means of telephone and/or personal visits. Also, follow-up phone calls were made with those mangers to communicate about distribution of the questionnaire. Later on, these questionnaires were collected manually.

Open-ended questions were used to gain in-depth insights about the implications of religion, culture and legislations on women's employment. The following questions were asked of the participants to understand how religion, culture and legislation affect the situation of female workers:

1. How would you describe the impact of religion (Islam) or its interpretation on women's employment and leadership in organizations in Jordan?

2. How would you explain the influence of the local culture and tribal traditions on women's employment and leadership in organizations in Jordan?

3. How would you explain the influence of the local laws on women's employment and leadership in organizations in Jordan?

\section{Data analysis}

All responses were read several times to grasp the overall picture of responses. Relevant responses were classified into short and long (in-depth) answers. The in-depth answers were further grouped to be either against or with females to participate in businesses and to be promoted into positions of power. After reading the responses, we determined the initial codes to capture a more comprehensive picture of the responses (see Table 3).

Each answer was manually coded, then, all relevant codes were grouped around common meanings (Fitzsimmons et al., 2014) in relation to the selected categories in the current research: religion, culture and legislation. Then, we consolidated the initial codes that 
Implications of religion, culture and legislation

emerged through a reflexive interpretation, and decided upon sub-theme. Then we counted the frequencies of each code to conclude more logical theoretical themes. This helped in verifying the relativeness between the sub-themes to explore how the three categories contribute in either hindering or supporting female workers. This also helped in testing out rigorous themes and yielded a holistic picture of the overall orientation for the participants.

\section{Insert Table 3 about here}

Overall, with further concentration on the in-depth answers (i.e. 68 questionnaires), the numbers of participants who believe that religion, culture and legislation are either with or against female workers are as follows. Out of 68 questionnaires, 57 participants answered the first question that concerns religion, 54 participants answered the second question in relation to cultural dimension and 46 participants answered the third question in relation to legislative system. This occurred because some participants did not fully answer the three questions.

In the first question, 46 participants believe that religion supports and allows females to work, while 11 participants indicated the opposite view. In relation to the cultural dimension, 39 participants argue that cultural practices may prevent females from economic participations, while 15 participants claim that cultural aspects have no impact on female's economic participation in the workplace. Finally, regarding the implications of the legislative system, 41 participants contend that legislation endorses and promotes gender equality, while 5 participants believe that legislation restricts female economic participation. This will be illustrated in the following section. 
Implications of religion, culture and legislation

\section{Determining theoretical categories and key themes}

Findings in this section highlight the implications of Islam, culture and legislation on women's advancement into positions of power in Jordan. According to the schematic illustrations of the emergent codes, key themes emerged in this stage by integrating the first order codes around common meanings and through developing theoretical categories (subthemes).

Three dominant themes emerged: (a) Islam promotes gender equality but it is misinterpreted, (b) tribal culture hinders female leaders, and (c) legal initiatives support gender equality. The following sections illustrate the theoretical categories that determine the three main themes.

\section{Theme One: Islam promotes gender equality but it is misinterpreted}

Figure 1 shows the most repeated codes in the responses to the question "how would you describe the impact of religion (Islam) or its interpretation on women's employment and leadership in organizations in Jordan?"

\section{Insert Figure 1 about here}

These codes were further grouped in order to have a rigor direction towards conceptualizing them into themes and sub-themes. There are two sub-themes that lead to and explain theme one, which are: (a) people's misinterpretation of Islam due to local/cultural traditions and customs and (b) the effect of work environment on females

Sub-theme One: People's misinterpretation of Islam due to local/cultural traditions and customs. This sub-theme emerged from the codes: interpretation of Islam and disgrace/shame in Figure (1). Interestingly, this sub-theme was agreed by the majority of participants regardless of gender. For example, a female customer relations manager expressed that "religion [Islam] supports women's rights and encourages them to be a part 
Implications of religion, culture and legislation

of society. However, the culture plays a crucial role in preventing this. Thus, there is no equality between males and females in leadership positions". This view was supported by a male chief accountant who claimed that "the religion [Islam] has no impact on any job women do. In contrast, the religion strengthens the spirit of leadership and the individual skills in the workplace”. In support to this statement, a male food and beverage manager suggested that "religion [Islam] doesn't prevent women and encourages both women and men to work together. One example of this is when women participated in wars during the life of the Prophet".

The interpretation of religion was mentioned by a female HR coordinator who indicated that "the negative impact comes from the wrong interpretation and old traditions". Furthermore, a female operator said that "the interpretation of religion [Islam] has significant impact". This was agreed by a male accountant, who reiterated the point that "the religious authority in our society has a significant negative impact on women's jobs. Not because of the religion itself, rather due to the wrong interpretation and understanding of the religion". A similar response retrieved from the open-ended questions by a male reservation manager, who argued that, "the wrong interpretation of the religion [Islam] has negative influence on women. For example, some people linked the interpretation of religion with traditions and customs.

The majority of participants (47 responses) noted that females encounter challenges arising from the patriarchal and tribal interpretations of Islam. They also noted that these interpretations are heavily influenced by local cultural traditions. The participants in general agreed with the broad idea of gender equality, but disagreed extensively about what that means and how this ought to be operationalized. This confusion may be attributed to the ongoing conflict between the egalitarian Islamic views of gender and the prevalent patriarchal tribal traditions. 
Implications of religion, culture and legislation

Sub-theme Two: The effect of work environment on females. In contrast to the first sub-theme discussed above, an opposite view emerged from the participants' responses. This sub-theme emerged from the codes: gender mixed places and work environment. Based on 57 answers about the impact of religion on female workers, 11 participants argue that there are some religious beliefs that may restrict female workers. For example, a male cost and purchases accountant said:

"Usually, female workers in the hotel sector are oppressed, especially when they need to work a night shift. Thus, society doesn't accept them and forces them to leave work even before holding leadership positions. Also, in the tourism sector, married women are more impacted than others. We notice that females left their jobs when they get married and when they have kids. In contrast, men are more guaranteed for the employer".

In this quotation there is a clear indication to the type of industry that females might not be able to work in to develop their leadership skills. In support of this, a male HR manager claimed that "the Islamic faith allows women to hold leadership positions and allows them to compete within jobs. However, these jobs should not have any negative physical outcomes or impact on their societal environment in order to protect and respect their nature of sympathy".

In relation to mixed-gender workplaces, a male cashier said, "I do not think that religion has an impact on women if they respect religion and they respect the rules of being in a gender mixed environment". A similar response was offered by a male receptionist who said that "Islam gives women the equality to work in all sectors and to hold leadership positions, however, they should follow the rules of 'khalwa' [i.e. gender segregation]". As noticed in this sub-theme, despite acknowledging gender equality, some participants hold the 
Implications of religion, culture and legislation

workplace responsible for creating an appropriate environment to enable gender segregation or female modesty.

Overall, considering all responses emerged within religion category, one dominant theme may be identified: i.e. Islam promotes gender equality but it is misinterpreted.

\section{Theme Two: Tribal culture hinders female leaders}

To better understand of how cultural values and practices affect the situation of female workers, we grouped the emergent codes around common sub-themes. Figure 2 shows the most frequent codes in the response to the question "how would you explain the influence of the local culture and tribal traditions on women's employment and leadership in organizations in Jordan?"

\section{Insert Figure 2 about here}

There are two sub-themes that explain how tribal culture hinders female leaders (a) culture, traditions and customs are barriers and (b) the new values of the 21 st century.

Sub-theme One: Culture, traditions and customs are barriers. This sub-theme emerged from the codes culture, customs, traditions, tribalism and disgrace/shame. For example, in relation to the negative role that tribal/Bedouin culture may play, a male food and beverage manager argued that "in Jordan, the traditions restrict women to work, because of the notion of disgrace. And this leads to negative communication in the society, because men believe that they are responsible, and as a result, this will prevent collaboration". Likewise, a male HR manager further confirmed this view by saying that "women are still restricted by inherited traditions and customs, despite the fact that religion allows them to work in many sectors. However, there are negative perceptions that may come from women themselves. Because women rely on men and because men are capable to hold burden especially in jobs that require efforts and long hours". In this quote, the participant talked about the reasons for rejecting women's leadership in addition to traditions and customs, which are: negative 
Implications of religion, culture and legislation

perceptions from women and the reliance of women on men. This was supported by a male, cost and purchases accountant, who indicated that "traditions reject women to work in low levels, so what do you expect about leadership positions! This was repeated by a male receptionist who said that the "society with no culture (the majority) that believes that women should stay at home”.

Sub-theme Two: The new values of the 21st century. Globalized change in the environment was discussed in terms of the "new values" facing tribal culture. A male chief accountant argued that "recently, women are open to all fields, and traditions and customs are restricted just in the rural areas, and there is no disgrace on women to work". Similar responses show that in the $21^{\text {st }}$ century, there is a new trend towards female leaders. For example, one participant (male, accounts payable) further confirmed this by claiming that "recently, we are witnessing flexibility trends" regarding female workers/leaders and "there is a decrease in the tribal notions". Furthermore, another male participant noticed that "the local culture and tribal traditions existed 20 or 30 years ago. Recently, there is nothing like this and women work in all sectors without any barriers". One participant mentioned the differences between urban and rural areas, he said: "In urban areas, there are no traditions and customs. Maybe these traditions and customs exist in rural areas"

Despite the impact of the globalized " $21^{\text {st" }}$ values, still the tribal culture hinders female leaders. The tribal culture has stronger influence on the society and their attitude towards female leadership.

\section{Theme Three: Legal initiatives support gender equality}

Figure 3 shows the most frequent codes in the response to the question "how would you explain the influence of the local laws on women's employment and leadership in organizations in Jordan?"

\section{Insert Figure 3 about here}


Implications of religion, culture and legislation

Within this category, 4 key codes have emerged: ‘positive action and special treatment', 'women's rights ', 'laws support women 'and 'fairness by laws.' These codes were grouped into one dominant theme i.e. legal initiatives support gender equality.

This theme was concluded by looking at the most frequent codes in the answers. As shown in Figure (3) 41 participants perceive legislation as a supporter of females. For example: A male cost and purchase accountant indicated that laws in Jordan "make women superior to men sometimes, and laws in Jordan are more sympathetic with women". This answer was agreed with by a female receptionist who claimed that the legislation framework in Jordan "allows women to work and hold leadership position" and was further confirmed by a male HR officer who suggested that laws in Jordan "give complete rights for both genders".

However, some views show that these initiatives by the law were not sufficient. For example, a male general cashier said that "laws support equality between males and females, however, recently, in some ministries and organizations, the law has a negative impact on females, such as minimizing the maternity and marriage leave". Likewise, a male cost and purchases accountant said that despite the fact that "the Jordanian law is more sympathetic with women, some females leave work before reaching any leadership positions".

Based on the quotations in Figure (3) it can be concluded that law supports gender equality. However, the development of females might be hindered despite that support of the legal framework in Jordan.

\section{Summary of key themes}

Figure 4 offers a summary of three key themes. The relationship between the main themes in the current study is evident from the connections between sub-themes that were mentioned above. Patriarchal misinterpretation of religion and the legal framework is initiated by cultural tradition to create social barriers to gender equality. This in turn leads to normative 
Implications of religion, culture and legislation

behavior with a continuous patriarchal practice of religion that has direct influence on local culture and customs; the legal framework of the country also tends to harmonize with culture and religion.

\section{Insert Figure 4 about here}

It is clear that cultural traditions and customs are embedded with religious interpretations and practices as well as the legal framework. This study shows that Islam is generally practiced through patriarchal understanding (particularly in relations to women) which is different from its egalitarian approach to gender (Syed and Van Buren, 2014). Thus, women in organizations are impacted through the patriarchal interpretation of Islam that requires them to acquire "their legitimacy in the society" (Afiouni, 2014, p. 316). In terms of the overlap between culture and Islamic teachings, it is arguable that some Islamic values "remain heavily influenced by local cultural traditions" (Syed and Ali, 2010, p. 465).

In terms of the Islamic legal framework or sharia, some laws formulated by the Muslim jurists in the early centuries of Islam tended to provide women a secondary status as per the prevalent social ethos (Engineer, 2008). In the present study, we have shown that cultural traditions also involve the application of laws and the reforms towards human rights. For example, some of efforts towards gender equality and the enactment of laws for justice, as Sonbol (2003) notes, may undermine women's situation further due to contradictions with local/tribal culture. When such regulations and laws contradict cultural values, efforts towards women's rights can be a problematic. Therefore, this study indicates that laws and regulations are weak tools to confront and rectify gender prejudice and discrimination.

\section{Results and discussion}

Interests in the careers of female leaders remains strong among scholars and practitioners. In previous studies, scrutinizing gender-based biased (e.g. prejudice and negative stereotypes) to 
Implications of religion, culture and legislation

justify the underrepresentation of women in the upper levels of organization has failed to offer a clear picture about the linkages between the cultural/religious implications and women's career status. Hence, this paper contributes to the existing literature by moving beyond gender-based biases, to comprehend the contextual biases against females. This study has highlighted the implications of religion, culture and legislation on the women's employment and advancement into positions of power in Jordan. In what follows we discuss the emergent themes and link them with the extant literature.

The dominant theme that emerged in the current inductive-content analysis for the religion category is that "Islam promotes gender equality but it is misinterpreted". This theme is supported by historical examples that indicate that Islam allows women to be engaged in economic activities. For example, Khadija, the Prophet Muhammad's first wife was an eminent business-person. In addition, there are many similar examples in Islamic history. Umar ibn Al-Khattab (the second caliph) appointed a woman (Ash-Shifaa' bint Abdullah) as the supervisor of markets in Madinah. Other Muslim women such as Khaula and Bint Makhramah were working in trade, while a female named Quila said to the Prophet, "I am a woman who buys and sells things" (Syed and Van Buren, 2014).

Also, this theme is supported by the extant literature. Based on a normative perspective of employment relations in Islam, Syed and Ali (2010) note that Islam encourages gender equality. Akhmetova (2016) argues that, in the early age of Islam, Muslim women were given positions of trust and high responsibility in the spheres of leadership. Muhammad Al-Ghazali argues that women's work and participation should be encouraged and welcomed. He further argues that Islam encourages equity between males and females. He however acknowledges that there are certain traditions and practices put by people and not by God which cripple women's progression (cited in Sidani, 2005). 
Implications of religion, culture and legislation

Marlow (1997) argues that rulers and Islamic scholars after the Prophet Muhammad began to rationalize the tribal system and the pervasive culture that led to a deviation from gender egalitarian directions in Islam (cited in Syed and Van Buren, 2014). Thus, several historical and political factors are embedded in the way of understanding and interpreting religions. Therefore, despite the directions towards equality by the Quran and Hadith, there is an overwhelming gap between male and female roles in the work place in MMCs and thus, it is important to understand why this gender gap is still massive in the Middle East and Arab countries. Therefore, as discussed above and in line with the literature, another category that may justify this gender gap and needs further exploration is culture.

Jordan is well known by its Arab and Bedouin culture that is rooted in social/tribal customs given that it is at the center of several Arab countries (e.g. Saudi Arabia and Iraq) (Abu-Tayeh, 2007). It is also shaped by different cultural backgrounds that combine a lifestyle associated with modernity and Bedouin climate. For example, in comparison to some neighbor countries (e.g. Saudi Arabia), women in Jordan have relatively more freedom such as the right to full education, freedom to drive, vote and to participate in different businesses (Jordan Tourism Board, 2010). Nevertheless, still, some of the high priorities in Jordan are the hospitality values and extended family traditions (Jordan Travel and Tourism, n.d) that revolve around village and rural life.

In reviewing the extant literature on the linkages between culture-based factors and women's status, one key explanation for the restricted participation and continued inequality in Jordan is the tribal customs and Bedouin traditions (Abu-Rabia-Quader and Oplatka, 2008). For example, Sawalha and Meaton (2012) shed light on the Jordanian culture, noting that tribal tradition and customs stem from Bedouin culture. These Bedouin and tribal customs have a major impact on business and on female participation in the workplace. 
Implications of religion, culture and legislation

Furthermore, Sonbol (2003) confirms this by arguing that it is not tribalism that should give gender relations validity, rather tribalism leads to a continuing patriarchal order.

Females in Jordan encounter some contextual challenges and constraints that prevent them from getting involved in the business life. It is arguable that the Jordanian Arab culture with the embedded tribal/local customs may justify the rarity of females in the workplace. Therefore, in line with the literature, our content analysis indicates a dominant theme that asserts the embedded role of tradition and custom on forbidding women from accessing the positions of power. The dominant theme is that "tribal culture hinders female leaders".

The third theme emerged in our analysis is that "legal initiatives support gender equality". As shown in the legislation section, there are some trends towards equality, human rights and justice as well as obligations to enact equality laws. However, despite the major plans and the regulatory and legislative reforms to address gender equality as serious actions by the government and policy makers, still, females are under-represented in comparison to their male counterparts in the workplace. One reason behind this may be the patriarchy and masculinity systems that involved in the regulatory framework which in turn may restrict female's needs through a patriarchal/male dominant discourse (National Coalition, 2012). Sonbol (2003) argues that the implementation of some laws may undermine women's situation further because they contradict some cultural values and beliefs. Therefore, it is conspicuous that in Jordan, some of these regulations and legitimizations can be a problematic because of their paradoxes with some cultural values and beliefs.

In relation to the Jordanian hotel industry, the results show that employees in this sector perceive the tribal customs to be the primary culprit to explain the gender gap, while most participants pointed to a progressive interpretation of the Islamic religion and pointed out some of the ways employment laws supported equality between men and women. 
Implications of religion, culture and legislation

\section{Limitations and future directions}

A limitation of this paper is the limited sample of 4-star and 5-star hotels. Future research could extend this study by drawing on a wider/different population in terms of size and industries. Furthermore, the interpretivism (inductive) approach in this paper is subject to a natural bias. Thus, scholars may explore these contextual and societal factors that may contribute in the gender gaps in employment and leadership through various research designs and study sites.

To carry this work forward, this paper may be used as a heuristic approach towards contextual examinations of the lack of female leaders in certain regions such as the Middle East and South Asia. In specific, as this study shows that the interpretations of Islam are socially located and tied to social practice and culture, there is a need for more thoroughly sociological explorations of how other religions may interact with gender studies.

In terms of gender relations in Islam, as this study reveals, the severe challenge lies in how patriarchal, tribal and narrow interpretations of Islam can be reformed towards gender egalitarian interpretations and practices. Given that Islam's normative teachings (i.e. what Prophet Muhammad revealed through the Quran and his traditions) are inconsistently followed in the Muslim world, and because they are commonly set apart either by an extremely conservative approach or cultural bias, future scholars may wish to study the similarities and differences between the normative Islam (e.g., based on Muslim scholars' interpretations) and Islamic feminism as a dynamic force that can play a role in evolving leadership opportunities and equality for women. Further, given the exploratory nature of this study, future studies are encouraged to scrutinize how the linkages between 'religion' and gender can be understood within the historical trajectories.

The current research also highlights other areas for future research that are not well addressed by the current primary studies. For example, expanding the domain of research 
Implications of religion, culture and legislation

beyond patriarchal and tribal interpretation of Islam would be useful in understanding how other cultural dimensions may impact people's explanation of Islam (e.g. clan and hierarchical cultures). More empirical research on the linkages between religions and gender is also needed, and much variation of research designs would be appropriate. In particular, a promising avenue for future studies would be to examine the differences between the conventional Western theories on religion and women alongside Arab or Middle Eastern approaches to gender equality. Scholars are encouraged to contrast the mainstream Western liberal individualist views of freedom and equality with egalitarian Islamic views on gender.

In addition, some major questions remain unclear in the literature. For example, how and why people stereotype notions of 'female' and 'successful leader' in certain societies, and do cultures and values justify the incongruity in female stereotype and leader stereotype. Future scholars may foster more effort to examine both the causes of these stereotypes and how they can be addressed in organizations. One theory that may help in this regard is the Role Congruity Theory (RCT) (Eagly and Karau, 2002). The extant literature acknowledges that gender stereotypes are just one factor (among many others) that may lead to the lack of women in leadership and thus, other factors (e.g., intersection of race, ethnicity and social class) may be taken into consideration (Tariq \& Syed, 2017). These issues may be addressed by future scholars through various research approaches and methodologies.

\section{Conclusion}

The theoretical grounding on Islamic women's status is lacking and sparse. The majority of studies on Islamic practices and women's status are normative in nature and lack in-depth analysis. This paper offers new insights about the overlapping between culture and religion and their implications on women's employment. In specific, it contributes to the extant literature by providing an alternative view to the general conceptions that hold Islam as a source that holds Muslims women back. Also, judging from the experiences of employees 
Implications of religion, culture and legislation

working in the hotel sector in Jordan, the study shows that what restricts women's employment and advancement are the local and tribal customs along with patriarchal interpretation of Islam.

As we have seen, there are pro-justice trends within Islamic theology, however, such trends towards egalitarianism are largely impacted by the tribal systems that encourage 'Bedou-cracy' and 'Sheikho-cracy' models of management. Although there is a recognition of women's capabilities within Islamic societies, the patriarchal models are reflected in interpretation of the Islamic teachings. Hence, businesses and policy makers must consider a pro-justice approach that takes into account and enables full utilization of women's skills and capabilities.

From a policy view, the findings encourage professionals to reform the patriarchal and tribal systems that impede women's employment and progress in the Middle East. This has a managerial relevance for decision makers and managers beyond the context of the hotel sector in Jordan, not least because this issue is a common problem faced by females in various industries. The goal of gender equality can be achieved by activating a justice system that enables full utilization of women's skills and capabilities by eliminating the gender discriminatory role of the tribal customs, also by identifying an opportunity to reform patriarchal interpretations of religion (Islam) towards egalitarian interpretations and practices.

\section{Compliance with Ethical Standards:}

Conflict of Interest: The authors declare that they have no conflict of interest.

Ethical approval: This paper does not contain any studies with animals performed by any of the authors.

Informed consent: Informed consent was obtained from all individual participants included in the study. 
Implications of religion, culture and legislation

\section{References}

Abu-Rabia-Queder, S. (2007). The activism of Bedouin women: Social and political resistance. HAGAR: Studies in Culture Polity and Identities, 7, 67-85. Retrieved from: http://www.bgu.ac.il.

Abu-Rabia-Quader, S., \& Oplatka, I. (2008). The power of femininity: Exploring the gender and ethnic experiences of Muslim women who accessed supervisory roles in a Bedouin society. Journal of Educational Administration, 46(3), 396-415. DOI: 10.1108/09578230810869301.

Abu-Tayeh, B. K. (2007). Organisational justice on work-related attitudes in selected commercial banks in Jordan (PhD Thesis). University of Salford.

Afiouni, F. (2014). Women's careers in the Arab Middle East: Understanding institutional constraints to the boundary less career view. Career Development International, 19(3), 314-336. doi:10.1108/CDI-05-2013-0061

Akhmetova, E. (2016). Women in Islamic Civilisation: Their Rights and Contributions. Islam and Civilisational Renewal (ICR), 7(4), 474-491.

Alnaimi, H. M. A. (2012). Relationship Marketing in the Jordanian Internet Sector: The Inchusion of Switching Behaviour and Relationship Bonds into Relationship Marketing Model. (PhD Thesis). Griffith University.

Amandeep, T.L., \& Ghorbani, A. (2014). Market Research Methodologies: Multi-Method and Qualitative Approaches: Multi-Method and Qualitative Approaches Advances in Marketing, Customer Relationship Management, and E-Services: USA: IGI Global.

Aune, K. (2015). Feminist spirituality as lived religion: How UK feminists forge religiospiritual lives. Gender \& Society, 29(1), 122-145. doi:10.1177/0891243214545681 
Implications of religion, culture and legislation

Barlas, A. (2001). Muslim women and sexual oppression: Reading liberation from the Quran. Macalester International, 10(1), 117-146. Retrieved from: http://digitalcommons. macalester.edu.

Bem, S. L. (1981). Gender schema theory: A cognitive account of sex typing. Psychological Review, 88(4), 354-364. DOI: 10.1037/0033-295X.88.4.354.

Bikner-Ahsbahs, A., Knipping, C., \& Presmeg, N. C. (Eds.). (2014). Approaches to Qualitative Research in Mathematics Education: Examples of Methodology and Methods. Springer.

Blumer, H. (2015). Internal Communication in Bangladeshi Ready-Made Garment Factories: Illustration of the Internal Communication System and Its Connection to Labor Unrest. Springer.

Brough, P., Brown, J. M., \& Biggs, A. (2015). Improving criminal justice workplaces: Translating theory and research into evidence-based practice (Vol. 32). Abingdon: Routledge.

Bryman, A. (2012). Social research methods. Oxford: Oxford University Press.

Calás, M. B., \& Smircich, L. (1996). From the 'woman's point of view': Feminist approaches to organization studies. London: SAGE publication.

Clifton, B. P. (2014). Laws may be ineffective if they don't reflect social norms. Retrieved fromhttps://news.stanford.edu/news/2014/november/social-norms-jackson112414.html.

Dougherty, C. (2010). A comparison of public and private sector earnings in Jordan. ILO.

Du, X. (2016). Does Confucianism reduce board gender diversity? Firm-level evidence from China. Journal of Business Ethics, 136(2), 399-436.

Eagly, A. H., \& Karau, S. J. (2002). Role congruity theory of prejudice toward female leaders. Psychological Review, 109(3), 573-598. 
Implications of religion, culture and legislation

Engineer, A. (2008). The rights of women in Islam. Sterling Publishers Pvt. Ltd.

Ferguson, L. (2011). Promoting gender equality and empowering women? Tourism and the third millennium development goal. Current Issues in Tourism, 14(3), 235-249.

Fiorenza, E. S. (2013). Critical feminist studies in religion. Critical Research on Religion, 1(1), 43-50. doi:10.1177/2050303213476112

Fitzsimmons, T. W., Callan, V. J., \& Paulsen, N. (2014). Gender disparity in the C-suite: Do male and female CEOs differ in how they reached the top? The Leadership Quarterly, 25(2), 245-266.

Gacitúa-Marió, E., \& Wodon, Q. (Eds.). (2001). Measurement and meaning: combining quantitative and qualitative methods for the analysis of poverty and social extension in Latin America (Vol. 518). World Bank Publications.

Gaillet, L. L., \& Eble, M. F. (2015). Primary research and writing: people, places, and spaces. Routledge.

Grünenfelder, J. (2013). Negotiating gender relations: Muslim women and formal employment in Pakistan's rural development sector. Gender, Work \& Organization, 20(6), 599-615. DOI: 10.1111/j.1468-0432.2012.00609.x.

Hanington, B., \& Martin, B. (2012). Universal methods of design: 100 ways to research complex problems, develop innovative ideas, and design effective solutions. Rockport Publishers.

Henderson, K. A. (2006). Dimensions of choice: Qualitative approaches to parks, recreation, tourism, sport, and leisure research. Venture Pub.

Hofstede, G. (1984). Cultural dimensions in management and planning. Asia Pacific journal of management, 1(2), 81-99.

Hsieh, H. F., \& Shannon, S. E. (2005). Three approaches to qualitative content analysis. Qualitative health research, 15(9), 1277-1288. 
Implications of religion, culture and legislation

Jawad, H. A. (1998). The rights of women in Islam: An authentic approach. New York: St. Martin's Press.

Jordan tourism board. (2010). Values \& Tradition. Retrieved from: http://na2.visitjordan.com/visitjordanna/GeneralInformation/ValuesTraditions/tabid/6 0/Default.aspx.

Jordan Travel and Tourism. (n.d). Jordan daily life and social customs. Retrieved from: http://www.jordantours-travel.com/index.php/jordan-travel-guide/traditions.

Kabasakal, H., \& Dastmalchian, A. (2001). Introduction to the special issue on leadership and culture in the Middle East. Applied Psychology an International Review, 50(4), 479488.

King, A. (2009). Islam, women and violence. Feminist Theology, 17(3), 292-328. doi:10.1177/0966735009102361

Klenke, K. (2016). Qualitative Research in the Study of Leadership (2nd Ed.). UK: Emerald Group Publishing Limited.

Kogovsek, M., \& Kogovsek, M. (2015). Hospitality and tourism gender issues remain unsolved: A call for research. Quaestus, (6), 194.

Llewellyn, D., \& Trzebiatowska, M. (2013). Secular and religious feminisms: A future of disconnection? Feminist Theology, 21(3), 244-258. doi:10.1177/0966735013484220

Lohmann, T. (2011). Labor Regulation and Female Labor Market Participation. Jordan: Deutsche Gesellschaftfür Internationale Zusammenarbeit (GIZ) GmbH, Economic Integration of Women' MENA.

Majcher-Teleon, A \& Ben Slimène O. (2009). Women and Work in Jordan. Case study of Tourism and ICT Sectors. European Training Foundation.

Malik, H. (1980). Islam and Women: Some Experiments in Qatar. Journal of South Asian and Middle Eastern Studies, 4(2), 3. 
Implications of religion, culture and legislation

Maltby, L. E., Hall, M. E. L., Anderson, T. L., \& Edwards, K. (2010). Religion and sexism: The moderating role of participant gender. Sex Roles, 62(9-10), 615-622.

Marco, R. (2012). Gender and economic performance: Evidence from the Spanish hotel industry. International Journal of Hospitality Management, 31(3), 981-989.

Marks, D. F., \& Yardley, L. (Eds.). (2004). Research methods for clinical and health psychology. Sage.

Mehar, I. A. (2003). Al-Islam: Inception to conclusion. Washington, DC.: Library of Congress.

Metcalfe, B. D. (2008). Women, management and globalization in the Middle East. Journal of Business Ethics, 83(1), 85-100.

National Centre for Human Resources Development. (2014). Human resources indicators in Jordan in 2014. Jordan: Author

National Coalition. (2012). Substantive Equality and Non-Discrimination in Jordan. The Arab Women Organization (AWO), Solidaridad International

Peebles, D., Darwazeh, N., Ghosheh, H., \& Sabbagh, A. (2007). Factors affecting women's participation in the private sector in Jordan. National Center for Human Resources Development, Canadian International Development Agency, Canada.

Pickthall, M. M. (1925). The Relation of the Sexes. Retrieved from: https://www.nikah.com/marriage/relation-of-the-sexes.asp

Rizzo, H. M. (2017). Islam, democracy and the status of women: the case of Kuwait. Abingdon: Routledge.

Sabri, H. A. (2011). Beyond Arab Spring: Societal Context and Prospects for a New Paradigm of Arab Management. Journal of Social and Development Sciences. 2(5), 214-222. 
Implications of religion, culture and legislation

Sawalha, I., \& Meaton, J. (2012). The Arabic culture of Jordan and its impacts on a wider Jordanian adoption of business continuity management. Journal of business continuity \& emergency planning, 6(1), 84-95.

Sechzer, J. A. (2004). Islam and Woman: Where Tradition Meets Modernity: History and Interpretations of Islamic Women's Status. Sex Roles, 51(5-6), 263-272.

Seedat, F. (2013). Islam, feminism, and Islamic feminism: Between inadequacy and inevitability. Journal of Feminist Studies in Religion, 29(2), 25-45.

Sidani, Y. (2005). Women, work, and Islam in Arab societies. Women in Management Review, 20(7), 498-512.

Social Security Corporation (2014). Annual report 2013: Statistical Appendix. Jordan: Author

Social Security Corporation. (2014). Woman \& Man in the Social Security: A Statistical Portrait. Amman. Author

Sonbol, A.E.A. (2003). Women of the Jordan: Islam, Labor, and the Law. USA: Syracuse University Press.

Sparkes, A. C., \& Smith, B. (2013). Qualitative research methods in sport, exercise and health: From process to product. Routledge.

Srinivasan, R. (2014). Services marketing: the Indian context. PHI Learning Pvt. Ltd.

Syed, J., \& Ali, A. J. (2010). Principles of employment relations in Islam: A normative view. Employee Relations, 32(5), 454-469. Doi: 10.1108/01425451011061630

Syed, J., \& Van Buren III, Harry J. (2014). Global business norms and Islamic views of women's employment. Business Ethics Quarterly, 24(2), 251-276. Doi: $10.5840 /$ beq 201452910 
Implications of religion, culture and legislation

Tariq, M., \& Syed, J. (2017). Intersectionality at work: South Asian Muslim women's experiences of employment and leadership in the United Kingdom. Sex Roles, 77(78), 510-522.

The Jordanian National Commission for Women. 2011. National Report Progress of Jordanian Women: In Pursuit of Justice, Participation and Equality. Jordan: JNCW

Tlaiss, H. A. (2015). How Islamic business ethics impact women entrepreneurs: Insights from four Arab Middle Eastern countries. Journal of Business Ethics, 129(4), 859877.

Turner, R., \& Freiermuth, E. (2017). Travel \& Tourism Economic Impact 2017 Jordan, World Travel and Tourism Council, Retrieved from: https://www.wttc.org//media/files/reports/economic-impact-research/countries-2017/jordan2017.pdf.

United Nations Development Programme. (2012). Gender Equality and Women's Empowerment in Public Administration: Jordan Case Study. New York: UNDP

World Bank. (2013). Country gender assessment: economic participation, agency and access to justice in Jordan. Washington, DC; World Bank Group

World Bank. (2014). Women in Jordan - Limited Economic Participation and Continued Inequality. Retrieved from:

http://www.worldbank.org/en/news/feature/2014/04/17/women-in-jordan---limitedeconomic-participation-and-continued-inequality 
Implications of religion, culture and legislation

Table 1 Employment and wages by gender in tourism and hotel sector

\begin{tabular}{lllc}
\hline Total tourism employment in Jordan & \multicolumn{3}{c}{$\mathbf{3 8 , 2 9 4}$} \\
\hline & Male & Female & Gender Gap \\
$\begin{array}{l}\text { Numbers of employees in tourism sector by } \\
\text { gender }\end{array}$ & 35.460 & 2.833 & 32.627 \\
$\begin{array}{l}\text { Numbers of employees in hotels (as a } \\
\begin{array}{l}\text { subsector) by gender } \\
\text { Monthly wages in tourism sector by gender }\end{array}\end{array}$ & 12.847 & 1.147 & 11.700 \\
\hline
\end{tabular}

Source: Adapted from Majcher-Teleon and Ben Slimène (2009) and Social Security Corporation (2014) 
Implications of religion, culture and legislation

Table 2 Number of employees distributed in 4-star and 5-star hotels by gender and governorate

\begin{tabular}{ccccccccc}
\hline Governorate & \multicolumn{2}{c}{ Amman } & \multicolumn{2}{c}{ Aqaba } & \multicolumn{2}{c}{ Dead Sea } & \multicolumn{2}{c}{ Petra } \\
\hline Hotel class & M & F & M & F & M & F & M & F \\
\hline 5-star & 4.244 & 389 & 1.235 & 24 & 2.090 & 169 & 590 & 9 \\
4-star & 1.798 & 132 & 290 & 12 & 366 & 17 & 276 & 3 \\
& & & & & & & & \\
\hline
\end{tabular}

Source: Adapted from Ministry of Tourism and Antiquities (2015) 
Implications of religion, culture and legislation

Table 3 Codes and frequencies

\begin{tabular}{|c|c|c|c|c|c|}
\hline Religion & Freq. & Culture & Freq. & Legislation & Freq. \\
\hline Religious conditions & 6 & $\begin{array}{l}\text { New values in the } 21^{\text {st }} \\
\text { century }\end{array}$ & 4 & Application of laws & 2 \\
\hline $\begin{array}{l}\text { Culture, customs and } \\
\text { traditions }\end{array}$ & 3 & Cultural ignorance & 1 & Cronyism & 1 \\
\hline Deficient in intelligence & 1 & Culture & 19 & Democratic country & 1 \\
\hline Disgrace / Shame & 1 & Customs & 9 & Fairness by laws & 15 \\
\hline Diversity & 1 & $\begin{array}{l}\text { Women's dependency on } \\
\text { men }\end{array}$ & 1 & Patriarchal system & 1 \\
\hline Efficiency of women & 1 & Disgrace / Shame & 7 & $\begin{array}{l}\text { Laws support } \\
\text { women }\end{array}$ & 6 \\
\hline Work environment & 5 & Educations level in Jordan & 1 & $\begin{array}{l}\text { Positive action and } \\
\text { special treatment }\end{array}$ & 6 \\
\hline $\begin{array}{l}\text { Protecting women's } \\
\text { femininity }\end{array}$ & 1 & Environment of work & 2 & Women's rights & 6 \\
\hline Hadith interpretation & 3 & $\begin{array}{l}\text { Protecting women's } \\
\text { femininity }\end{array}$ & 3 & Wrong laws & 2 \\
\hline \multirow[t]{2}{*}{ Interpretation of Islam } & 6 & Freedom for women & 1 & & \\
\hline & & Gender mixed places & 3 & & \\
\hline Gender justice & 1 & Openness culture & 1 & & \\
\hline Gender mixed places & 7 & $\begin{array}{l}\text { Health and educational } \\
\text { sector }\end{array}$ & 2 & & \\
\hline \multirow[t]{2}{*}{ Racism against women } & 2 & Traditions & 23 & & \\
\hline & & Tribalism & 9 & & \\
\hline Superiority for women & 1 & Women' rights & 1 & & \\
\hline $\begin{array}{l}\text { Sympathetic nature of } \\
\text { women }\end{array}$ & 2 & & & & \\
\hline
\end{tabular}


Figure 1: The emergence of Theme One: Islam promotes gender equality but it is misinterpreted

\section{[Religion prohibits]}

11 participants show that religion is against women to work and hold leadership positions. Some examples are as follows:

"Never will succeed such a nation as lets their affairs carried out by a woman" (Hadith).

"It is prohibited and considered disgraceful."

"If there is a gender mixed environment this prevents women to work."

"Religion prevents gender mixed environment."

"Women are not allowed to work in mixed gender workplaces"

"Women should be at their home to be away from non-Mahrams."

Initial codes
Codes

\section{[Religion supports]}

46 participants show that religion is with women to work and hold leadership positions. Some examples are as follows:

"Women in Islam are not prevented from being leaders."

"Islam does not prevent women to work when women respect her religion and respect the rules of being in a mixed gender environment."

"Religious authority in our society has a significant negative impact on women' jobs. Not because of the religion itself, rather due to the wrong interpretation and understanding of the religion."

"Islamic religion makes women and men equal and protect women's rights."

"There are no problems unless the work is acceptable."

"It encourages women and men to work together."

"Work is a worship for both male and female."

Initial codes 
Figure 2: The emergence of Theme Two: Tribal culture hinders female leaders

\section{[Culture prohibits]}

39 participants show that culture restricts women from working and holding leadership positions. Some examples are as follows:

"Traditions and customs are barriers."

"Women in Jordan are impacted by traditions and customs."

"Culture, traditions, and customs have a large influence." "Traditions prevent women to work."

"Traditions in our country are stricter than religion on women."

Initial codes

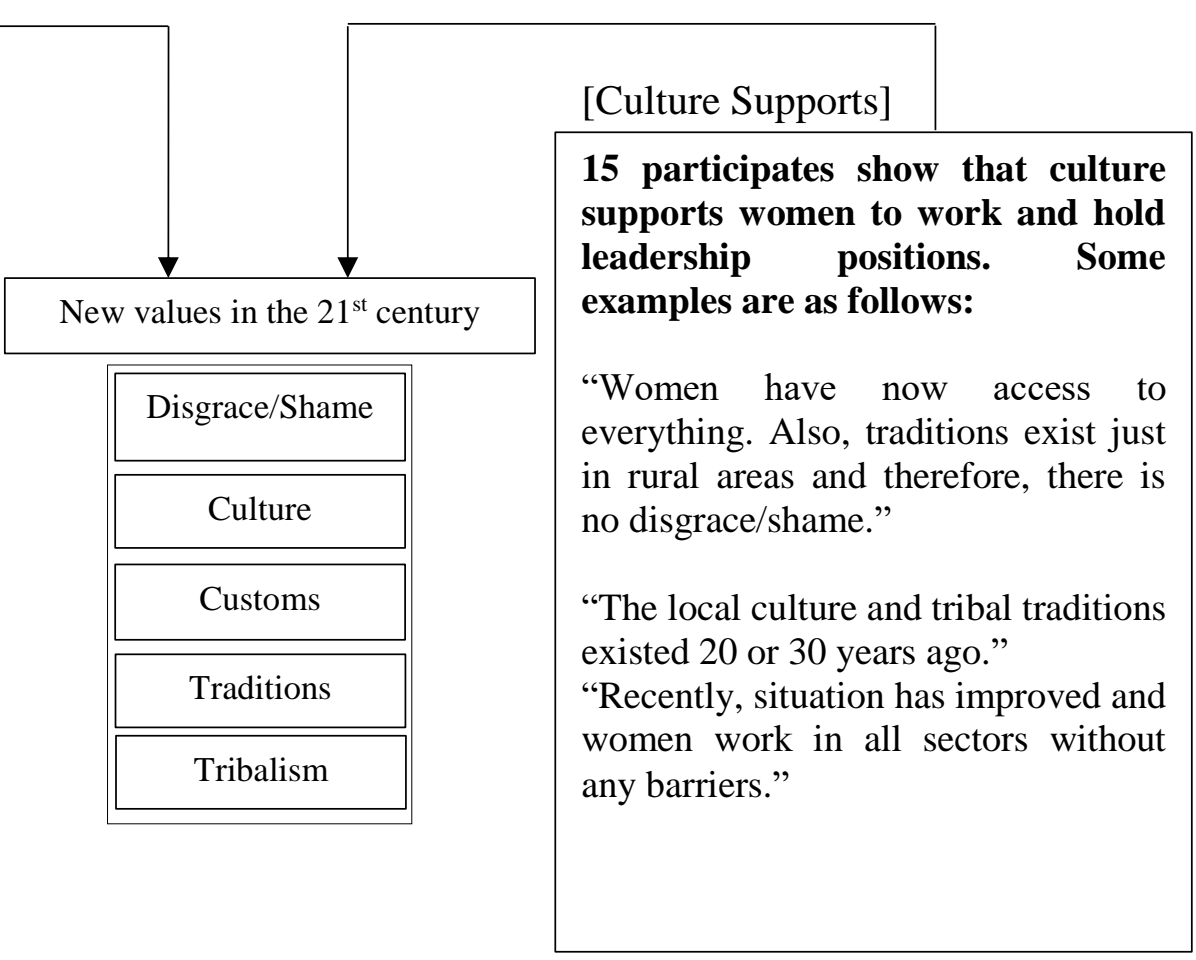

Codes
Initial codes 
Figure 3 The emergence of Theme Three: Legal initiatives support gender equality

\begin{tabular}{|c|}
\hline \\
\hline $\begin{array}{l}5 \text { participates show that } \\
\text { legislations are against } \\
\text { women to work and hold } \\
\text { leadership positions } \\
\text { Some examples are as } \\
\text { follows: } \\
\text { "Laws are not fair." } \\
\text { "Those who constituted } \\
\text { these laws did not take } \\
\text { into account women's } \\
\text { rights ever." }\end{array}$ \\
\hline
\end{tabular}

Initial codes

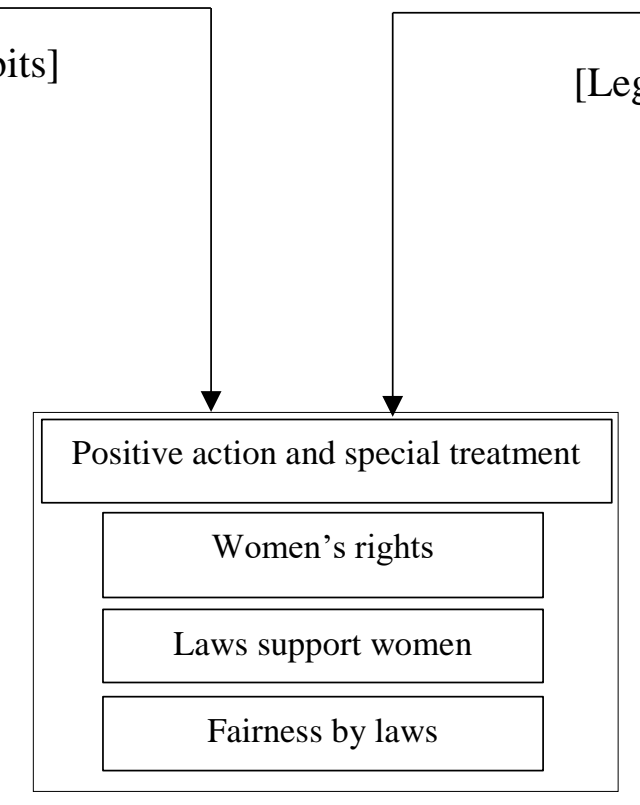

Codes
Legislation supports]

41 participants show that legislations are with women to work and hold leadership positions. Some examples are as follows:

"It leads to equality between men and women."

"It allows women to work and hold leadership positions."

"Supports women to work and hold high level positions."

"Supports women."

"Labor laws give women all their rights."

Initial codes 
Implications of religion, culture and legislation

Figure 4 An overview of the key themes

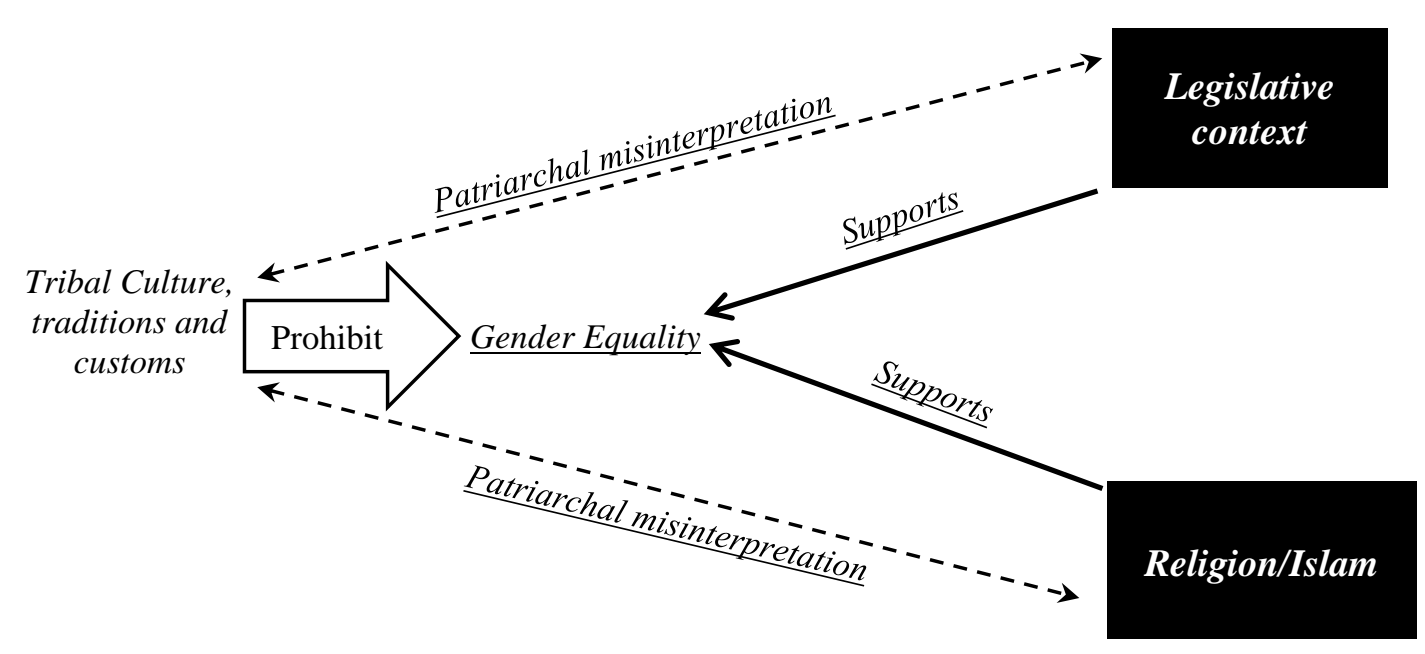

